\title{
ANTIBACTERIAL EFFECT OF EUGENIA POLYANTHA WIGHT WITH CORYNEBACTERIUM DIPHTHERIAE NON-TOXIGENIC
}

\author{
Ivita T Murbarani ${ }^{1)}$, Endang Isbandiati $^{2)}$, Chrisdina Puspitasari ${ }^{3)}$
}

\begin{abstract}
Introduction: Corynebacterium diphtheriae is a bacteria that causes diphtheria. In recent years, the bacterium is resistant to antibiotics. Eugenia polyantha wight might be a suitable antibiotic alternative as it has antibacterial effect against Staphylococcus aureus. The content of the antibacterial compound in Eugenia polyantha wight at specific concentrations is expected to be able to kill the Corynebacterium diphtheriae.

Purpose: This study aimed to examine the antibacterial effect of Eugenia polyantha wight to Corynebacterium diphtheriae non-toxic.

Method: Bay leaf extract (Eugenia polyantha wight) made with maceration method. This research is an experimental study conducted in vitro using a microdilution test on 96 well plates then count value with the streaking method to find out MBC.

Results: bactericidal power was quite effective at the concentration of $40 \%$, while at the concentration of $80 \%-100 \%$ has very strong bactericidal power that could destroy the growth of bacteria $99.9 \%$. The higher the concentration of bay leaves extract, the higher the bactericidal power of bacteria

Conclusion: Eugenia polyantha wight has an antibacterial effect against Corynebacterium diphtheriae non-toxic.
\end{abstract}

Keywords: MBC, bay leaf, Eugenia polyantha wight, Corynebacterium diphtheriae non toxic.

\footnotetext{
${ }^{1)}$ Student of Faculty of Medicine, Widya Mandala Surabaya Catholic University Indonesia, Jl. Kalisari Selatan No.1 Surabaya Email: Vitatahta3@gmail.com

${ }^{2)}$ Clinical Pharmacology Department, Faculty of Medicine, Widya Mandala Surabaya Catholic University Indonesia, Jl. Kalisari Selatan No.1 Surabaya

${ }^{3)}$ Medical Biology Department, Faculty of Medicine, Widya Mandala Surabaya Catholic University Indonesia, Jl. Kalisari Selatan No.1 Surabaya
} 


\section{INTRODUCTION}

There are still many diseases that are caused by an infection in many developing countries. For instance, the infections caused by Corynebacterium diphtheriae which is a non-motile Grampositive basil. These bacteria can infect the nasopharynx and skin. Toxinresistant strains of bacteria produce strong exotoxins that can cause diphtheria ${ }^{1}$. Diphtheria is a rare occurrence in Indonesia today.

Diphtheria is an acute respiratory tract disease that spreads through direct contact with the droplet of patients removed from the respiratory tract and direct contact with the skin lesions. The most common diphtheria is local to the respiratory tract, which is at the back of the mouth and upper larynx. The incidence of resistance to antibiotics has increased. According to a Brazilian study, Corynebacterium diphtheriae isolates have begun to show resistance to seven drugs: ampicillin, oxygen, tetracycline, and linkomycin clindamycin, and erythrromycin ${ }^{3}$. Nowadays, many researchers are interested in finding alternative antimicrobial therapies, especially from plant $^{4}$.

Bay leaves has the Latin name Eugenia polyantha wight and another scientific name, Syzygium polyantha wight or Eugenia lucidula Miq. Bay leaves have been developed in the medical field as an alternative medicinal plant. Bay leaves have several beneficial chemical ingredients. One of them is used for the treatment of Reccurent apthous stomatitis (RAS) $)^{5}$ Eugenia polyantha wight contains flavonoids, tannins, essential oils, saponins, poliferols, alkaloids, and pesticides with antibacterial activity $^{6}$. Recent studies have shown that Eugenia polyantha wight can reduce streptococcus $\mathrm{sp}$ colonies in samples rinsed with Eugenia polyantha wight solution at $100 \%, 75 \%$, $50 \%$ concentration. Empirically, Eugenia polyantha wight shows benefits for hypertension, diabetes, diarrhea, gastritis, and skin diseases. This bay leaf also has other benefits such as diuretic and analgesic effects ${ }^{5}$.

There are no studies on the antibacterial effect of bay leaf extract (Eugenia polyantha wight) on Corynebacterium diphtheriae. Hence, the purpose of this study is to determine the antibacterial effect of bay leaf (Eugenia polyantha wight) on Corynebacterium diphtheriae by finding the Minimum Bactericide Concentration (MBC) value of Eugenia polyantha wight leaf extract on Corynebacterium diphtheriae. 


\section{METHOD}

This study was an experimental study using a true experiment with the Static Group Comparison method divided into two groups: treatment and control groups. The study was conducted at the Widya Mandala Surabaya Catholic University, Faculty of Pharmacy Research Laboratory, and Surabaya General Hospital Clinical Laboratory (BBLK) Clinical Microbiology Laboratory. The population of this study was the non-toxic Corynebacterium diphtheriae bacteria. The sample taken was Corynebacterium diphtheriae bacterium NCTC 10648 obtained from the BBLK Clinical Microbiology Laboratory. The concentration of saliva concentration used was $20 \%, 30 \%, 40 \%, 80 \%$, and $100 \%$.

\section{Bay Leaf Preparation}

The leaf samples used were from the district of Kediri, East Java. Fresh salads were extracted at the Widya Mandala Surabaya Catholic University, Faculty of Pharmacy Research Laboratory, and obtained from Simplisia bay leaf. Salad syrup was performed by $96 \%$ ethanol extraction and received as a concentrated liquid extract of bay leaf extract and then diluted with $20 \%, 30 \%, 40 \%, 80 \%$, and $100 \%$ concentration.

\section{Manufacture of Bacterial}

\section{Suspensions}

The bacterial culture stock that was grown was sterilized and suspended in a $0.9 \% \mathrm{NaCl}$ solution to a bacterial suspension volume equal to $0.5 \mathrm{Mc}$ Farland standard on a 1.5 x $108 \mathrm{Mc}$ Farland densitometer CFU/ml ${ }^{11}$.

\section{Antibacterial Testing}

Antibacterial activity testing was performed by using a macroscopic method to propagate the bacteria. This study was divided into control and treatment groups with a volume of well $150 \mu \mathrm{L}$.

\section{Control group K1-5consisting of:}

$\mathrm{K} 1=$ Mueller-Hinton Broth with Blood K2 $=$ Mueller-Hinton Broth with Blood + Corynebacterium diphtheriae (Control -) K3 = Mueller-Hinton Broth with Blood + Corynebacterium diphtheriae + Penicillin $0.12 \mathrm{mg}($ Control +$)$

\section{Control group P1-5 consisting of:}

P1 = Mueller-Hinton Broth with Blood + Corynebacterium diphtheriae + Euginea polyantha wight leaf extract $100 \%$ concentration P2 = Mueller -Hinton Broth with Blood + Corynebacterium

diphtheriae + Euginea polyantha wight leaf extract $80 \%$ concentration 
P3 = Mueller-Hinton Broth with Blood + Corynebacterium diphtheriae + Euginea polyantha wight leaf extract $40 \%$ concentration.

P4 = Mueller Hinton Broth with Blood + Corynebacterium diphtheriae + Euginea polyantha wight leaf extract $30 \%$ concentration.

P5 $=$ Mueller Hinton Broth with Blood + Corynebacterium diphtheriae + Euginea polyantha wight leaf extract concentrated $20 \%$.

$\mathrm{Q} 1=$ in the media for the growth detection of Corynebacterium diphtheriae by streaking method to find $\mathrm{MBC}$ values.

Determination of $\mathrm{MBC}$ bay leaves against Corynebacterium diphtheriae was counting the number of colonies from streaking crops. Streaking was performed by pouring $0.5 \mu \mathrm{L}$ of extract into the media for Mueller Hinton Broth with Blood and then incubated at $35^{\circ} \mathrm{C}$ for 24 hours.

\section{RESULTS}

\section{The Average Result Count Number of Colonies (CFU/ml)}

Based on this result, it was showed that bactericidal power was quite effective at the concentration of $40 \%$, while at the concentration of $80 \%$ $100 \%$ has very strong bactericidal power that could destroy the growth of bacteria 99.9\%. According to Lee et al., it can be assumed that the high phytol concentration in bay leaves which was about $5,715 \%$, was able to have antibacterial activity. In a study conducted by Dewi Apriani et al., 60\% dose was quite effective in killing bacteria, while at $80 \%$, it was able to kill bacteria very effectively. The higher the concentration of bay leaves extract, the higher the bactericidal power of Concentration Count Number of Colonies (CFU/ml)

\begin{tabular}{cc}
\hline P1 $100 \%$ & TAP \\
\hline P2 $80 \%$ & TAP \\
\hline P3 $40 \%$ & 58.8 \\
\hline P4 30\% & $>10^{5}$ \\
\hline P5 20\% & $>10^{5}$ \\
\hline
\end{tabular}

bacteria ${ }^{7}$.

Observatian Result of Visual Test in Bay Leaf

$\begin{array}{llllll}\begin{array}{l}\text { Treatm } \\ \text { ent }\end{array} & \text { P1 } & \text { P2 } & \text { P3 } & \text { P4 } & \text { P5 }\end{array}$

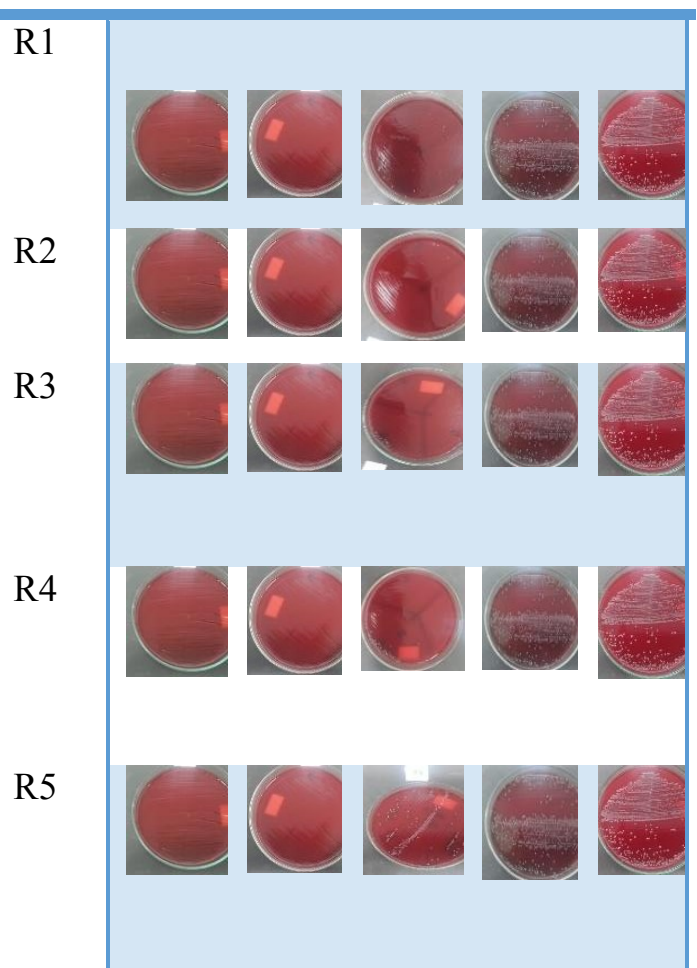




\section{Graphic of Colony Count Resistance Test}

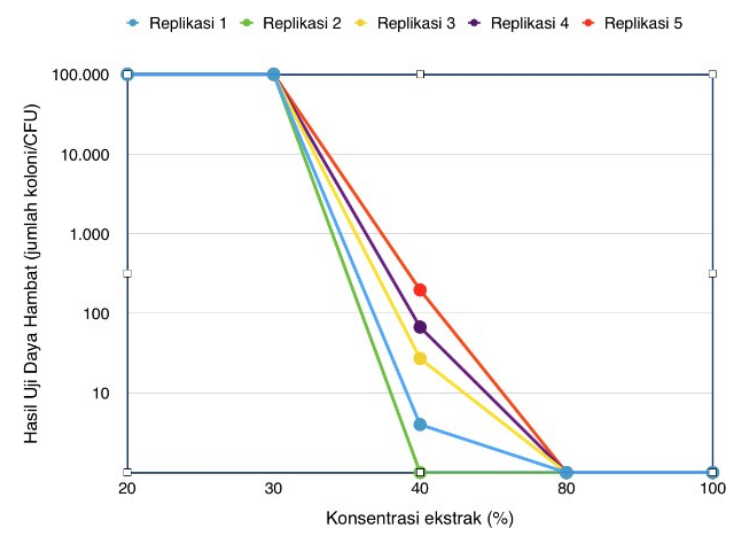

The graph above showed five replications of the bacterium Corynebacterium diphtheria treatment. The graph showed that the higher the concentration of the bay leaf extract, the higher the bactericidal level. In five replicates at $80 \%-100 \%$ concentration a decrease in bacterial growth were observed. At $40 \%$ concentration, there were fluctuations in bacterial growth, resulting in results fluctuation since the concentration of phytol compounds at $40 \%$ was less effective and resulted in fluctuating results. The second replication showed bacterial growth of $0 \mathrm{CFU} / \mathrm{ml}$, whereas the $5^{\text {th }}$ replication showed the highest bacterial growth of 196 $\mathrm{CFU} / \mathrm{ml}$. Five replicates at a concentration of $20 \%-30 \%$ showed the highest bacterial growth $^{7}$.

\section{DISCUSSION}

This study first performed identification. Identification was conducted by using various methods. The first method used to identify the bacteria studied was Gram positive or Gram negative by using Gram. There were Gram-positive bacteria in Gram painting, indicated by purple colour in Gram's painting. The purple color is the result of the bacteria retaining the violet crystal colour ${ }^{8}$.

Biochemical tests were performed using the PYZ test, Cysteines test, Nitrate test, and Urease test to differentiate with other Corynebacteria. The first test was the PYZ test. In this case, Corynebacterium diphtheriae showed no color change until yellow interpreted PYZ test results negative. This was because Corynebacterium diphtheriae did not have pyrazinamide enzyme, which will be converted to free pyrazinoic $\operatorname{acid}^{9,10}$. Cysteines test obtained colony growth of Corynebacterium diphtheriae which found brown halo formation in the colony that was showing positive test result, halo in colony formed by cysteines enzyme contained in Corynebacterium diphtheriae in the form of brown strain in media ${ }^{11} 10$. After that, the Nitrate test obtained a change of pink color interpreted as a positive nitrate test. The color change in this test resulted from nitrate converted to nitrite by Corynebacterium diphtheriae12 10. Next, it was continued by Urease test. This test obtained results 
in the form of pink color in the media that was positively interpreted in the urease test, and pink color was due to the urea content of the Corynebacterium diphtheriae, which was broken into ammonia which resulted in a color change in this test ${ }^{10,13}$..

After, specific identification of the bacteria using Cysteine tellurite blood agar (CTBA) media, this test was performed by bacterial propagation on tellurite-containing media, which identified the result of the growth of the black colony. The black colony resulting from Corynebacterium diphtheriae decreased tellurite becomes tellurium in CTBA media, causing the colony to turn black. In contrast, other bacteria are unable to metabolize tellurite in the media and would die ${ }^{14}$.

This bacteria was also identified by using blood plate media because in this study, Mueller-Hinton broth with blood media was expected to provide nutrients for the growth of Corynebacterium diphtheria. This identification was used to determine which bacteria can grow well in the blood media. the result of growth was the appearance of white and round colonies ${ }^{10-15}$.

We used bay leaf in this experiment because bay leaf was expected to have antibacterial benefits ${ }^{6}$. Bay leaf was used to treat Recurrent apthous stomatitis (RAS) because bay leaf was assumed to reduce the disease by reducing inflammation and has 91 antibacterial effect ${ }^{5}$. A study by Dewi Apriani et al. showed efficacy of saliva infusions concentration on antibacterial power was found at $60 \%$ concentration to effectively inhibit bacterial growth, whereas at $80 \%$ concentration it effectively inhibited bacterial growth; hence, this study used the basis of giving the concentration at $20 \%$, $30 \%, 40 \%, 80 \%$, and $100 \%$. The writer would like to prove the least effective dose to kill Corynebacterium diphtheria in this study ${ }^{7}$.

The extraction of ethanol extracts was conducted by maceration method. The method of masking was chosen because it preserves the most stable compounds and a straightforward method. It was obtained the extraction results in the form of condensed precursors that were diluted using $2 \%$ DMSO solution and aiming to use $2 \%$ DMSO solution to homogenize the extract while using aquades to dilute the extract. Then the result of the dilution was put into a glass envelope and taken to BBLK Surabaya.

In this study, the use of streaking method was performed at BBLK Surabaya. There were seven groups, namely, the treatment group and the control group. The treatment group was replicated five times to strengthen the validity of the data obtained and as anticipatory measure if replication failed in the experiment.

This study was performed two times. 
The first experiment was a failure when using ethanol leaf extract at an initial concentration of $100 \mathrm{mg} / \mathrm{ml}$ with a dilution concentration of $2.5 \%, 5 \%, 10 \%, 20 \%$, and $40 \%$. The results obtained were attributed to the low concentration of compounds whose antibacterial activity was not able to inhibit the bacteria.

The second study used ethanol leaf extract by increasing the initial concentration of $150 \mathrm{mg} / \mathrm{ml}$ and diluted it with the extract concentration increased to $20 \%, 30 \%, 40 \%, 80 \%$, and $100 \%$. It was estimated that we could find the Minimum Bactericidal Concentration (MBC). MBC results showed no bacterial growth at $80 \%$ $100 \%$ concentration, but at $20 \%-40 \%$ concentration, we begin to see bacterial colony growth on the media. In colony count, results obtained at $80 \%-100 \%$ concentration there was no colony growth. At a concentration of $40 \%$, the average growth of the bacterial colony was 58.8 $\mathrm{CFU} / \mathrm{ml}$, whereas the concentration of $20 \%$ $-30 \%$ of the average growth of the bacterial colony was $>105 \mathrm{CFU} / \mathrm{ml}$. Based on the results, it can be concluded that there was a decrease in the number of Corynebacterium diphtheria colony as a result of ethanol bay leaf extract, which can be seen from the growth of bacterial colonies, which has reached the Minimum Kill Rate (MBC), which was inhibition of $99.9 \%$ bacterial growth $^{16}$.
The study conducted by Sri Agung Fitri et al., who examined the antibacterial activity of bay leaves against bacteria, gave $\mathrm{MBC}$ results in the concentration range of $10 \%-20 \%$ showing bacterial death ${ }^{17}$.

According to the study of Dewi Apriani et al., at $60 \%$ concentration bay leaf was quite effective in inhibiting bacterial growth. In comparison, at $80 \%$ concentration it was very effective in inhibiting bacterial growth ${ }^{7}$.

a study by Erlena et al. showed that the highest chemical compounds in the bay leaf were squalene $(8.345 \%)$, phytol (5.715\%), $\beta$-sitosterol (4.959\%), and less than $4 \%$ were other components. Phytol compounds have biological activity that is antimicrobial $^{18}$. The study that was examined by Wonjong Lee et al. noted that phytol compounds have a strong bactericidal effect, cell death due to phytol compounds has a mechanism by which ROS accumulates mediates oxidative stress that results in damage to bacterial DNA ${ }^{19}$.

Based on the study results, it is recognized that bay leaf extract has high phytol compounds and antibacterial effect on the Corynebacterium diphtheriae mediated by oxidative stress, causing damage to bacterial DNA. Based on the result, it was revealed that the concentration factor of the extract influences the antibacterial effect. The higher the concentration of the extract, the higher the 
destructive potential. This study obtained MBC values in the concentration range of $80 \%-100 \%$ in plate count calculations, which inhibited the Corynebacterium diphtheriae $99.9 \%$ by leaf extract (Eugenia polyantha wight) ${ }^{16}$.

\section{CONCLUSION}

Eugenia polyantha wight bay leaf ethanol extract at $80 \%-100 \%$ concentration is verified to be toxic to Corynebacterium diphtheriae.

\section{ACKNOWLEDGEMENT}

Faculty of Medicine, Widya Mandala Catholic University of Surabaya, Pharmacy of Widya Mandala Catholic University of Surabaya, Clinical Microbiology Laboratory, and Centre for Health Laboratory (BBLK) Surabaya.

\section{REFERENCES}

1. Baron S. Medical Microbiology. 4th edition. University of Texas Medical Branch at Galveston. 1996.

2. dinas kesehatan provinsi jawa timur. No Title. Penanggulangan KLB Difteri di Provinsi Jawa Timur. Surabaya: IDAI Cabang Jawa Timur; 2018. 9-11 p.

3. Pereira GA, Pimenta FP, Dos Santos
FRW, Damasco PV, Hirata R, Mattos-Guaraldi AL. Antimicrobial resistance among Brazilian Corynebacterium diphtheriae strains. Mem Inst Oswaldo Cruz. 2008;103(5):507-10.

4. Ismail A, Ahmad WANW. Syzygium polyanthum (Wight) Walp: A Potential Phytomedicine. Pharmacogn J. 2019;11(2):429-38.

5. Sumono A, SD AW. The use of bay leaf (Eugenia polyantha Wight) in dentistry. Dent J (Majalah Kedokt Gigi). 2016;41(3):147.

6. Harismah K, Chusniatun. Pemanfaatan Daun Salam (Eugenia polyantha) Sebagai Obat Herbal dan Rempah Penyedap Makanan. War LPM. 2016;

7. Apriani D, Amaliawati N, Kurniati

E. Efektivitas Berbagai Konsentrasi Infusa Daun Salam (Eugenia polyantha Wight) terhadap Daya Antibakteri Staphylococcus aureus Secara In Vitro. Teknol Lab. 2014;

8. Edition E. Brock Biology of Microorganisms. Cell. 2006;

9. Revathi G, Talwar V. A biochemical test based on pyrazinamidase activity for rapid differentiation ofcorynebacteria. Indian $\mathrm{J} \quad \mathrm{Clin}$ Biochem. 1995; 
10. Putranto RH, Sariadji K, Sunarno, Roselinda.

Corynebacterium diphtheriae: Diagnosis Laboratorium

Bakteriologi. 2014. p. 67.

11. Colman G, Weaver E, Efstratiou A. Screening tests for pathogenic corynebacteria. J Clin Pathol. 1992;

12. Smith LD. Texbook of Microbiology. William Burrows. Saunders, Philadelphia, Pa., ed. 17, 1959. xxxiii +954 pp. Illus. \$14. Science (80- ). 1960;

13. Lim D. Microbiology. New York: McGraw-Hill; 2006.

14. Sariadji K, Sunarno S, Khariri K, Puspandari N, Muna F, Rukminiati

Y. Selektivitas Medium Cystine Tellurite Blood Agar (CTBA) terhadap Beberapa Isolat Bakteri. J Kefarmasian Indones. 2017;5(1):19- 24.

15. Dwi Krihariyani, Evy Diah Woelansari EK. Pola Pertumbuhan Staphylococcus aureus Pada Media Agar Darah Manusia Golongan $\mathrm{O}, \mathrm{AB}$, dan Darah Domba Sebagai Kontrol. Ilmu dan Teknol Kesehat. 2016;3, nomor 2 .
16. Taylor PC, Schoenknecht FD, Sherris JC, Linner EC. Determination of minimum bactericidal concentrations of oxacillin for Staphylococcus aureus: Influence and significance of technical factors. Antimicrob Agents Chemother. 1983;

17. Sri Agung FK, Ramdhani D, Mustarichie R. Comparative study on activities of anti bacillary dysentry Shigella dysenteriae of Syzygium polyanthum and Dracaena angustifolia leaves ethanol extracts. Asian J Pharm Clin Res. 2017;

18. Asmira Abd Rahim EN, Ismail A, Omar MN, Rahmat UN, Nizam Wan Ahmad WA. GC-MS analysis of phytochemical compounds in syzygium polyanthum leaves extracted using ultrasound-assisted method. Pharmacogn J. 2018;

19. Lee W, Woo ER, Lee DG. Phytol has antibacterial property by inducing oxidative stress response in Pseudomonas aeruginosa. Free Radic Res. 2016 